\title{
UJI EFEKTIVITAS LARVASIDA DAUN MIMBA (Azadirachta indica) TERHADAP LARVA LALAT Sarcophaga PADA DAGING UNTUK UPAKARA YADNYA DI BALI
}

\author{
A.A. Lidya Nirmala Dewi, I W. Karta, N.L. Candra Wati, N.M. Andini Dewi \\ Jurusan Analis Kesehatan, Politeknik Kesehatan Denpasar \\ Denpasar, Indonesia \\ Email: lidya.nirmaladewi@gmail.com, iwayankartaganesh@gmail.com
}

\begin{abstract}
Abstrak
Jenis Lalat Sarchopaga dapat merusak daging yang digunakan dalam sarana upacara yadnya di Bali yang dapat menimbulkan bau dan tampilan tidak menarik. Berbagai cara telah dilakukan untuk mengatasinya, namun belum optimal dapat menanggulanginya. Pada penelitian ini akan digunakan daun mimba (Azadirachta indica) untuk mencegah pengaruh negatif dari lalat ini. Tujuan penelitian ini untuk mendeskripsikan efektivitas larvasida daun mimba terhadap larva lalat Sarchopaga pada daging yang digunakan sebagai sarana upakara di Bali. Kelompok perlakuan ini yaitu penggunaan daun mimba $25 \%$ sebagai larvasida, kelompok kontrol positif yaitu penggunaan minuman bersoda, dan kelompok kontrol negatif yaitu tidak mendapat perlakuan. Hasil uji One Way Anova diperoleh hasil nilai probabilitas $p(0,000)$ $<\alpha(0,05)$ yang menunjukkan adanya perbedaan jumlah kematian larva pada perlakuan rebusan daun mimba $25 \%$, kontrol negatif dan kontrol positif. Perlakuan daun mimba konsentrasi $25 \%$ memberikan jumlah kematian larva yang lebih tinggi dibandingkan terhadap kontrol positif dengan perbedaan persentase sebesar $60 \%$. Daun mimba lebih efektif sebagai larvasida jika dibandingkan dengan minuman bersoda. Perebusan daging dengan menambahkan daun mimba dapat digunakan untuk menghindari pembusukan yang disebarkan oleh lalat daging (Sarchopaga).
\end{abstract}

Kata kunci : daun mimba, lalat daging, larvasida

\begin{abstract}
Sarchopaga Flies type can damage the meat used in the ritual paraphernalia yadnya in Bali that can cause odors and unattractive appearance. Various ways have been made to handle it, but not optimal can cope. This research will be used leaves of neem (Azadirachta indica) to prevent the negative effects of these flies. The purpose of this study to describe the effectiveness of neem leaf larvicides against Sarchopaga fly larvae in meat is used as a means upakara in Bali. The treatment group, namely the use of neem leaves $25 \%$ as larvicides, the positive control group, namely the use of soft drinks, and a negative control group that did not receive treatment. One Way test results obtained by the results of the probability $\mathrm{p}(0.000)<\alpha(0.05)$ which shows the difference in the number of larvae mortality in the treatment of neem leaf decoction of $25 \%$, negative control and a positive control. Treatment of neem leaf concentration of $25 \%$ gives the number of larval mortality is higher than the positive control with the difference in the percentage of $60 \%$. Neem leaf was found to be more effective as larvicides when compared to soft drinks. Boiling meat by adding neem leaves can be used to avoid decomposition spread by the flies meat (Sarchopaga).
\end{abstract}

Key words: Azadirachta indica, larvicides, Sarchopaga

\section{PENDAHULUAN}

Lalat merupakan jenis serangga, termasuk subordo Cyclorrapha, ordo Diptera yang sering di jumpai dalam keseharian kita dan pada hampir semua jenis lingkungan. Di ekosistem lalat dapat berperan dalam proses pembusukan, sebagai predator, parasit pada serangga, sebagai pollinator (Byrd \& Castner, 2001), penyebab myasis (David, B.V., Anathakrishnan, 2004), dan dapat 
berperan sebagai vektor penyakit saluran pencernaan seperti kolera, typhus, disentri (Santi, 2001). Lalat juga dapat membawa bakteri patogen, Protozoa, telur serta larva cacing (Chandra, 2005). Lalat dapat menularkan penyakit melalui bahan makanan atau minuman yang terkontaminasi oleh bibit penyakit yang menempel pada tubuh, kaki, tarsi (Graczyk, Knight, \& Tamang, 2005) dan proboscis. Lalat menimbulkan adanya belatungan pada media yang dihinggapi dan tempat media bertelurnya. Hal ini menimbulkan penampilan yang buruk dan bau tidak sedap pada media seperti daging.

Salah satu jenis lalat yang tidak sehat bagi lingkungan yaitu lalat daging. Lalat ini termasuk dalam genus Sarcophaga, artinya pemakan daging. Larva dari banyak jenis-jenis lalat ini hidup dalam daging, tetapi pembiakan bisa juga terjadi dalam kotoran binatang (Santi, 2001). Lalat ini tentunya merugikan bagi masyarakat, karena menyebabkan terjadinya percepatan pembusukan, salah satunya adalah sarana upakara yadnya yang menggunakan daging di Bali. Upakara yadnya atau dikenal dengan banten merupakan sarana persembahan dalam upacara keagamaan agama Hindu yang menggunakan bahan dari daging seperti babi, ayam, sapi, kerbau, ikan, dan daging lainnya (Sudarsana, 2010). Lalat Sarcophaga sering menghinggapi dan bertelur pada sarana upakara yang terbuat dari daging, seperti banten bangun, bebangkit. Sarana upakara ini biasanya menggunakan daging yang direbus dan dibuat dengan kreativitas sedemikian rupa membentuk bentuk-bentuk tertentu. Bebantenan ini biasanya didiamkan sampai upacara keagamaan selesai. Dengan adanya lalat daging, menyebabkan terjadinya pembusukan dan bau yang tidak sedap.

Masyarakat Bali yang beragama Hindu melakukan antisipasi terhadap serangan lalat daging seperti Sarcophaga terhadap daging pada banten upacara yadnya. Antisipasi yang dilakukan dengan menyemprotkan minuman bersoda dan beralkohol pada daging. Namun, cara ini belum efektif karena setelah alkohol menguap, lalat kembali menghinggapi daging. Oleh karena itu, diperlukan suatu upaya terbarukan dengan memanfaatkan bahan lokal yang memiliki aktivitas sebagai larvasida ataupun insektisida. Bahan lokal yang dapat digunakan yaitu daun mimba (Azadirachta indica).

Daun mimba di Bali dikenal dengan daun intaran. Daun ini sering digunakan sebagai dedaunan dalam upakara yadnya dan sebagai symbol alis pada saat menghias jenazah sebelum dikubur atau dikremasi. Daun mimba telah diteliti memiliki kandungan aktif yang bermanfaat sebagai anti-inflamasi, antitumor, efek diuretik, insektisida, anti jamur, anti bakteri, larvasida nyamuk, dan antimalarial (Biswas, Chattopadhyay, Banerjee, \& Bandyopadhyay, 2002). Tanaman mimba mengandung zat aktif azadiractin, minyak gliserida, polifenol, acetiloksifuranil dekahidrotetrametil acid, ksosiklopentanatoffiiran, asetat-keton, monoterpen, dan heksahidrositetrametil fenantenon (nimbol) (Hariana, 2013). Senyawa seperti azadirachtin berfungsi sebagai antifeedant (mencegah) dan sebagai repellent (penolak) sehingga sebagai insektisida dan larvasida. Ekstrak daun mimba lebih aman dan efisien digunakan karena mudah diperoleh, tidak toksik terhadap manusia serta mudah terurai sehingga aman bagi lingkungan (Kardinan, 2000).

Azadirachtin berdampak pada pertumbuhan semua fase larva serangga, pupa, dan serangga dewasa. Mekanisme kerjanya akan mempengaruhi metabolisme hormon serangga pada otak. Semakin tinggi konsentrasi Azadirachtin, maka jumlah racun yang mengenai kulit serangga semakin banyak, sehingga dapat menghambat pertumbuhan dan menyebabkan kematian serangga lebih banyak. Senyawa Azadirachtin dapat menghambat pertumbuhan serangga hama, mengurangi nafsu makan, mengurangi produksi dan penetasan telur, meningkatkan mortalitas, mengaktifkan infertilitas dan menolak hama di sekitar pohon mimba. Ekstrak mimba yang terbuat dari daun, bunga, dan biji mimba dapat digunakan untuk mengendalikan berbagai jenis hama, misalnya Helopelthis sp., ulat jengkal, Aphis sp., Nilarvata sp., dan 
Sitophilus sp. Daun mimba juga dapat meningkatkan mortalitas larva nyamuk (Fathoni, Yanuwiadi, \& Leksono, 2013).

Tanaman mimba (Azadirachta indica), terutama dalam biji dan daunnya mengandung beberapa komponen dari produksi metabolit sekunder seperti azadirachtin, salanin, meliantriol, nimbin dan nimbidin yang diduga sangat bermanfaat, baik dalam bidang pertanian (pestisida dan pupuk), maupun farmasi (kosmetik dan obat-obatan. Mimba mempunyai spektrum yang luas, efektif untuk mengendalikan serangga lunak (200 spesies) antara lain belalang, trips, ulat, kupu-kupu putih dan lain-lain. Penggunaan daun mimba sebagai pestisida alam yang aman bagi mahkluk hidup dan lingkungan. Berdasarkan hal tersebut, maka dalam penelitian ini akan diuji aktivitas larvasida daun mimba terhadap lalat Sarchopaga pada daging yang digunakan sebagai sarana upakara di Bali. Hal ini berkaitan dengan kandungan-kandungan dalam daun mimba akan terserap pada daging saat proses perendaman, sehingga nantinya dapat sebagai larvasida larva lalat daging.

\section{METODE}

Jenis penelitian yang digunakan adalah penelitian True-experimental (eksperimen murni). Desain penelitian yang digunakan yaitu Posttest only-control design. Dalam penelitian ini variabel bebas adalah rebusan daun mimba dengan konsentrasi $25 \%$. Variabel terikatnya yaitu jumlah kematian larva sebagai potensi larvasida daun mimba terhadap pertumbuhan larva Sarchopaga. Variabel kontrolnya adalah suhu perebusan daun, ukuran daging, umur larva, air perebusan, lama perebusan.

Objek dalam penelitian ini adalah daun mimba (Azadirachta indica). Daun yang digunakan adalah daun tanaman mimba yang tidak terlalu muda atau terlalu tua, berwarna hijau tua dan tidak berlubang (diambil sebanyak 15 helai dari setelah 5 helai dari pucuk). Daun mimba dengan helaian berbentuk memanjang lanset bengkok, panjang 3-10 cm, lebar 0,5-3,5 $\mathrm{cm}$, pangkal runcing tidak simetri, tepi daun bergerigi kasar, remasan berasa pahit, warna hijau muda. Tangkai panjang 8-20 $\mathrm{cm}$. Diperlukan 250 gram daun mimba segar dalam 1 liter air untuk memperoleh rebusan daun mimba konsentrasi $25 \%$.

Penelitian ini dilakukan di Lab Kimia Dasar dan Kimia Terapan Jurusan Analis Kesehatan Polteknik Kesehatan Denpasar. Penelitian ini dilakukan selama 5 bulan pada tahun 2016. Alat-alat yang digunakan dalam penelitian ini yaitu, neraca analitik, gelas kimia, gelas ukur, pisau, mangkok plastik, nampan, saringan teh, plastik bening, talenan, botol air mineral, panci, jarum, dan tempat/wadah untuk uji larvasida. Bahan yang digunakan yaitu daun mimba muda yang diambil 15 cabang daun dari pucuk, akuades, minuman soda, darah babi, daging babi yang biasanya untuk pembuatan upakara dan hewan uji berupa larva lalat daging (Sarchopaga) instar III awal.

Larva lalat daging dipersiapkan dengan mengembangbiakan lalat daging. Alat dan bahan dipersiapkan untuk mengembangbiakan seperti mangkok kecil, plastik bening, daging babi, darah, dan botol air mineral. Plastik bening diletakkan pada mangkok, kemudian ditaruh daging babi yang sudah dipotong dan ditambahkan darah babi secukupnya. Kemudian ditempatkan dan disinari cahaya matahari dan ditunggu hingga banyak lalat yang hinggap pada daging. Selajutnya, dilakukan identifikasi lalat yang hinggap pada daging babi. Lalat daging dipisahkan dan dipindahkan ke dalam botol. Dipindahkan kembali lalat daging ke mangkok lain yang telah berisi daging dan darah babi untuk memulai proses perkembangbiakan lalat. Larva ditunggu kira-kira 4-5 hari hingga menjadi instar III. Hasil pemeliharaan diperoleh persediaan larva instar III awal untuk pengujian.

Unit analisis dalam penelitian ini adalah aktivitas larvasida daun mimba terhadap pertumbuhan larva lalat Sarchopaga pada daging yang digunakan sebagai sarana upakara di Bali. Pertumbuhan larva lalat Sarchopaga pada daging diamati dalam tiga perlakuan yaitu salah satu daging akan direndam dengan air rebusan daun mimba sebanyak 250 gram dalam $1 \mathrm{~L}$ air sehingga konsentrasi 
daun mimba menjadi $25 \%$, kemudian daging yang lain direndam dengan softdrink sekaligus sebagai kontrol positif, dan perlakuan ketiga adalah daging yang tidak diberi perlakuan apapun sekaligus sebagai kontrol negatif.

Terdapat tiga perlakuan terhadap daging babi. Jumlah pengulangan rendaman daun mimba konsentrasi $25 \%$ yaitu sebesar 10 ekor sedangkan jumlah larva mati paling kecil dari seluruh pengulangan dan replikasi terdapat pada kontrol negatif yaitu sebesar 0 ekor. Untuk lebih jelasnya dapat dilihat pada Tabel 1.

Pada uji efektivitas larvasida peneliti mempergunakan 2 buah kontrol, yaitu kontrol positif dan kontrol negatif. Untuk

Tabel 1. Rerata Jumlah Larva Mati Pada Konsentrasi Air Rebusan Daun Mimba (Azadirachta indica) $25 \%$, Kontrol Negatif, dan Kontrol Positif

\begin{tabular}{|c|c|c|c|c|c|c|c|c|c|c|c|}
\hline \multirow[t]{2}{*}{$\begin{array}{l}\text { Konsentrasi } \\
\text { (perlakuan) }\end{array}$} & \multicolumn{3}{|c|}{$\begin{array}{c}\text { Replikasi I } \\
\text { Pengulangan }\end{array}$} & \multicolumn{3}{|c|}{$\begin{array}{c}\text { Replikasi II } \\
\text { Pengulangan }\end{array}$} & \multicolumn{3}{|c|}{$\begin{array}{l}\text { Replikasi III } \\
\text { Pengulangan }\end{array}$} & \multirow[t]{2}{*}{$\begin{array}{l}\text { Rata- } \\
\text { rata }\end{array}$} & \multirow{2}{*}{$\begin{array}{c}\text { Persentase } \\
\text { Kematian } \\
\text { Larva }\end{array}$} \\
\hline & 1 & II & III & 1 & II & III & I & II & III & & \\
\hline $25 \%$ & 10 & 10 & 10 & 10 & 10 & 10 & 10 & 10 & 10 & 10 & $100 \%$ \\
\hline K - & 0 & 0 & 0 & 0 & 0 & 0 & 0 & 0 & 0 & 0 & $0 \%$ \\
\hline $\mathrm{K}+$ & 3 & 5 & 3 & 5 & 7 & 5 & 3 & 3 & 2 & 4 & $40 \%$ \\
\hline
\end{tabular}

sebanyak tiga kali dan replikasi sebanyak tiga kali. Pengulangan yang dimadsud yaitu menggunakan rendaman sampel yang sama yang dilakukan sebanyak tiga kali (triplo), sedangkan replikasi yaitu pengulangan kembali perlakuan yang sama dalam suatu eksperimen, dengan kondisi eksperimen yang sama pula. Berdasarkan pengulangan dan replikasi diperoleh 27 data.

Pengujian larvasida dilakukan dengan dengan metode rancangan acak lengkap. Masing-masing daging dengan perlakuan yang berbeda ditempatkan pada wadah uji larvasida. Wadah ini terbuat dari gelas besar yang ditutup dengan kertas yang dilubangi kecil-kecil. Kemudian dimasukkan 10 ekor larva lalat daging pada setiap perlakuan, dan didiamkan. Pengamatan dilakukan setiap 1 hari sampai 7 hari. Pengamatan dilakukan dengan cara menghitung jumlah larva yang mati (mortalitas larva). Selain itu diamati secara kualitatif tekstur daging dan bau.

Analisa data dilakukan dengan uji Anova untuk menguji ada atau tidak ada perbedaan rata-rata pada masing-masing sampel pada perlakuan atau kelompok yang lebih dari dua.

\section{HASIL DAN PEMBAHASAN}

Rerata jumlah larva mati paling besar dari seluruh pengulangan dan replikasi terdapat pada perlakuan dengan kontrol positif peneliti mempergunakan daging yang direndam selama 30 menit dengan minuman bersoda. Sedangkan untuk kontrol negatif peneliti mempergunakan daging tanpa perlakuan. Uji kedua kontrol tersebut turut dilakukan tiap kali melakukan uji efektifitas larvasida lalat daging (sarchopaga) dengan daun mimba. Adapun tujuan dari pengerjaan kontrol positif dan negatif ialah sebagai pembanding terhadap perlakuan dalam uji larvasida.

Pada kontrol negatif, peneliti mempergunakan daging yang dipotong dengan ukuran $15 \mathrm{~cm} \times 5 \mathrm{~cm} \times 2 \mathrm{~cm}$ dan prosedur pengerjaan yang dilakukan hanya dengan meletakkan daging tanpa penambahan apapun pada toples kemudian ditambahkan 10 ekor larva lalat instar ketiga. Alasan menggunakan larva instar ketiga adalah karena larva instar ketiga memiliki kemampuan yang lebih baik dalam menetralisir senyawa toksik.

Larva yang diletakkan pada daging tanpa perlakuan diamati bersamaan dengan larva yang diletakkan pada daging yang direndam dengan rebusan daun mimba konsentrasi $25 \%$ dan daging yang direndam dengan minuman bersoda. Adapun hasil yang didapat pada kontrol negatif selama pengujian efektifitas larvasida ialah larva mati sebanyak $0 \%$ atau hidup semua selama 7 hari. Hal ini 
terjadi karena pada daging tidak ditambahkan zat apapun yang mampu menghambat pertumbuhan larva. Sehingga larva yang diletakkan pada daging tanpa perlakuan dapat hidup dengan baik selama 7 hari.

Pada kontrol positif, peneliti mempergunakan daging yang dipotong dengan ukuran $15 \mathrm{~cm} \times 5 \mathrm{~cm} \times 2 \mathrm{~cm}$ kemudian direndam dengan minuman bersoda. Pada replikasi pertama ditemukan larva lalat sarcophaga yang mati di hari ketujuh dengan tiga pengulangan, masing-masing yaitu 3, 5, dan 3 larva. Pada replikasi kedua ditemukan larva lalat sarcophaga yang mati di hari ketujuh dengan tiga pengulangan, masing-masing yaitu 5, 7, dan 5 larva. Pada replikasi ketiga ditemukan larva lalat sarcophaga yang mati di hari ketujuh dengan tiga pengulangan, masing-masing yaitu 3, 3, dan 2 larva.

\section{Pengujian efektivitas larvasida} mempergunakan daun mimba dilakukan dengan cara yang sama dengan perlakuan daging pada kontrol positif. Daging dipotong terlebih dahulu dengan ukuran yang telah ditentukan, yaitu $15 \mathrm{~cm} \times 5 \mathrm{~cm} \mathrm{x}$ $2 \mathrm{~cm}$ kemudian direndam dalam rebusan daun mimba $25 \%$. Konsentrasi $25 \%$ dibuat dari daun mimba yang dipetik kemudian ditimbang 250 gram kemudian ditambahkan air sebanyak 1 liter, dan direbus selama beberapa menit hingga mendidih. Setelah daun direbus, air rebusan daun mimba digunakan untuk merendam daging babi selama 30 menit. Setelah 30 menit, daging kemudian diangkat dan diletakkan pada toples yang telah disiapkan, kemudian ditambahkan larva lalat daging sebanyak 10 ekor dan diamati jumlah larva yang mati selama 7 hari. Replikasi pertama dengan tiga kali pengulangan ialah seluruh larva mati pada hari ketujuh. Replikasi kedua dengan tiga kali pengulangan ialah seluruh larva mati pada hari ketujuh. Replikasi ketika dengan tiga kali pengulangan ialah seluruh larva mati pda hari ketujuh.

Data jumlah kematian larva yang diperoleh dalam penelitian ini kemudian dianalisis menggunakan uji statistik. Hasil uji statistik menunjukkan data berdistribusi normal. Uji dilakukan dengan Kruskal
Wallis untuk mengetahui adanya perbedaan jumlah kematian larva pada perlakuan rebusan daun mimba $25 \%$, kontrol negatif dan kontrol positif. Setelah diperiksa dengan tingkat kepercayaan 95 $\%(0,05)$ diperoleh hasil nilai probabilitas $p$ $(0,000)<\alpha(0,05)$ yang menandakan bahwa ada perbedaan jumlah kematian larva pada perlakuan rebusan daun mimba $25 \%$, kontrol negatif dan kontrol positif.

Pada kontrol positif, peneliti mempergunakan daging yang direndam dengan minuman bersoda. Minuman soda merupakan jenis minuman yang berasal dari olahan air berkarbonasi. Karbondioksida yang diabsorbsikan ke dalam air, menyebabkan air menjadi berbusa. Maka dari itu pada sejumlah masyarakat memanfaatkan sifat pengawet dalam minuman ini untuk mengawetkan daging atau makanan lainnya. Serta minuman bersoda ini umum ditemukan dan mudah didapatkan di lingkungan sekitar. Maka dari itu peneliti mempergunakan minuman bersoda ini sebagai kontrol positif.

Daging yang direndam selama 30 menit dalam minuman bersoda mampu menyerap air karbonasi dari minuman bersoda, sehingga daging tersebut mengandung air berkarbonasi. Adanya larva lalat yang mati pada kontrol positif tersebut diakibatkan oleh bau khas dari minuman bersoda yang berasal dari air karbonasi menyebabkan larva tidak memakan daging tersebut, sehingga beberapa larva tidak dapat bertahan hidup selama 7 hari.

Kematian yang dialami oleh seluruh larva terjadi akibat dari adanya metabolit sekunder utama dalam tanaman mimba yang berfungsi sebagai insektisida yaitu azadirachtin yang terbentuk secara alami berupa substansi yang termasuk dalam kelas molekul organik tetranortriterpenoids. Senyawa dari daun mimba azadirachtin merupakan salah satu jenis senyawa yang cukup aktif yang tidak langsung mematikan serangga akan tetapi melalui proses mekanisme menolak makan, menganggu pertumbuhan dan reproduksi serangga (Pritima, R.A., Pandian, 2008). Adapun proses perebusan daun berfungsi untuk 
membuat zat-zat aktif dalam daun mimba keluar dan tercampus dalam air rebusan. Air rebusan tersebut kemudian digunakan untuk merendam daging selama 30 menit. Sehingga dapat terserap secara merata dalam daging dan mempengaruhi rasa serta memberi efek bagi larva.

daun malam uji ini, efektivitas larvasida membandingkan perbedaan jumlah larva lalat yang mati pada perlakuan daun mimba konsentrasi $25 \%$ dengan perlakuan minuman bersoda sebagai kontrol positif. Adapun persentase kematian larva lalat daging (Sarchopaga) hingga hari ke-7 (Tabel 1) pada kontrol positif (minuman bersoda) adalah $40 \%$, sementara kematian pada daun mimba konsentrasi $25 \%$ adalah $100 \%$. Berdasarkan pengamatan tabel tersebut diketahui bahwa perlakuan daun mimba konsentrasi 25\% memberikan jumlah kematian larva yang lebih tinggi dibandingkan terhadap kontrol positif dengan perbedaan persentase sebesar $60 \%$. Sehingga dapat dikatakan bahwa daun mimba lebih efektif sebagai larvasida jika dibandingkan dengan minuman bersoda.

Penelitian dilakukan dalam 3 replikasi yang tiap replikasinya terdapat pengulangan sebanyak 3 kali. Dari seluruh pengujian larvasida, seluruhnya menunjukkan jumlah kematian larva yang berbeda meskipun pada perlakuan yang sama. Melalui uji statistik diketahui bahwa terdapat perbedaan jumlah kematian larva lalat daging (Sarchopaga) antara perlakuan dengan daun mimba konsentrasi $25 \%$ dan minuman bersoda.

Timbulnya efek kematian terhadap larva lalat daging (Sarchopaga) pada perlakuan daun mimba konsentrasi $25 \%$ disebabkan oleh kandungan zat aktif pada daun mimba yaitu azadirachtin yang mampu bertindak sebagai antifeedant, ecdyson blocker, serta gangguan perkembangan dan reproduksi serangga. Azadirachtin juga berfungsi sebagai insektisida bagi beberapa jenis serangga. Kematian serangga dapat terjadi dalam beberapa hari, tergantung dari stadia dan siklus hidup serangga target. Akan tetapi, apabila termakan dalam jumlah kecil saja mengakibatkan serangga tidak bergerak dan berhenti makan. Aktivitas residu insektisida dari azadirachtin ini umumnya terjadi antara tujuh sampai 10 hari atau lebih lama lagi, tergantung dari jenis serangga dan aplikasinya (Samsudin, 2011). Azadirachtin yang dimakan serangga meskipun dalam jumlah kecil akan mengakibatkan serangga tidak dapat bergerak dan berhenti makan.

Azadirachtin memiliki efek primer berupa antifeedant dengan menghasilkan stimulan penolak makan spesifik berupa chemoreceptor pada bagian mulut yang mengganggu persepsi rangsangan untuk makan (Mordue (Luntz) et al., 1998). Azadirachtin juga memiliki efek sekunder berupa gangguan perkembangan dan reproduksi yang berefek langsung pada sel somatik dan jaringan reproduksi, disamping itu juga berefek tidak langsung terhadap terganggunya proses neuroendocrine. Efek sekunder lainnya yaitu sebagai ecdyson blocker yang menghambat serangga untuk memproduksi dan melepas hormon ecdyson yang bersumber dari sel-sel neurosekretori (Gambar 1). Kemampuan azadirachtin untuk memasuki organ neurosekretori dan ujung sel saraf dalam organ mempunyai komponen memblokir transmisi produk-produk dari neurosekretori. Adanya efek ini menyebabkan serangga akan terganggu pada proses pergantian kulit, ataupun proses perubahan dari telur menjadi larva, atau dari larva menjadi kepompong atau dari kepompong menjadi dewasa. Biasanya kegagalan dalam proses ini seringkali mengakibatkan kematian pada serangga.

Perlakuan dengan daun mimba konsentrasi $25 \%$ mampu memberi efek penolak makan sehingga terjadilah kematian seluruh larva pada hari ke-7. Hormon ecdyson pada serangga mengatur proses metamorfosa serangga, dimana produksi hormon ecdyson membantu serangga dalam pembentukan kutikula 


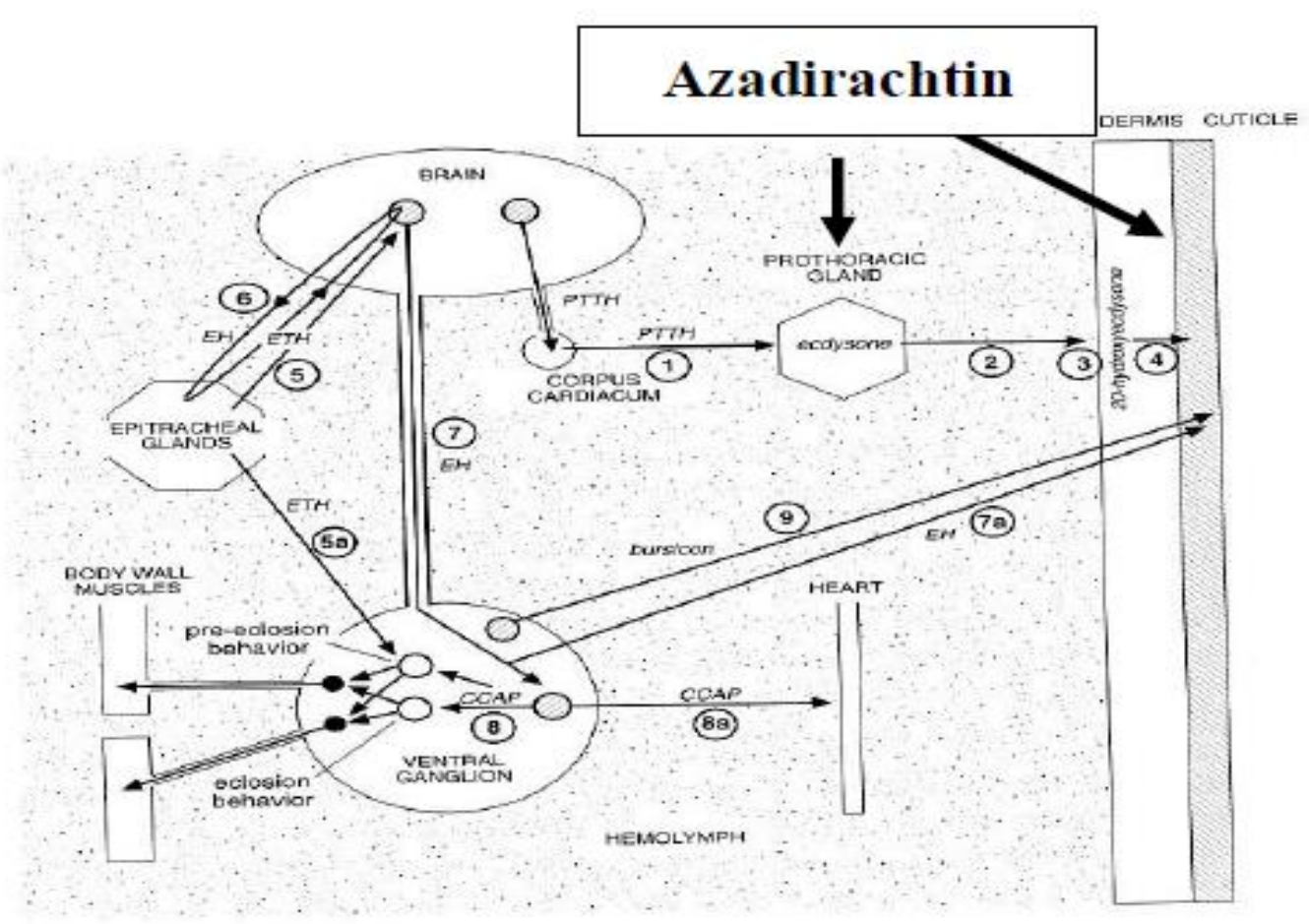

Gambar 1. Azadirachtin

baru serta enzimnya berpengaruh pada pengelupasan kulit. Azadirachtin pada daun mimba yang menghambat hormon ecdyson akan berakibat pada terganggunya proses pergantian kulit serangga. Sehingga apabila ada serangga yang terpapar maka hormon ecdyson akan menghambat bagian otak untuk menghasilkan hormon yang paling penting bagi pertumbuhan dan perkembangan serangga. Padahal tubuh serangga sudah siap untuk berubah namun hormon untuk berganti kulit (moulting) tidak terbentuk akhirnya siklus hidup serangga terganggu sehingga biasanya kegagalan dalam proses ini seringkali juga mengakibatkan kematian pada serangga (Susanti, Sukesi, \& Soeyoko, 2012).

Senyawa kimia azadirachtin dapat menghambat proses ganti kulit dengan merusak sistem fisiologi serangga. Azadirachtin juga dapat merusak sistem kerja hormon dan merusak sistem kominikasi kimiawi dalam proses ganti kulit. Mekanisme ganti kulit dipicu dan dikendalikan oleh otak $\mathrm{AH}$ (activation hormone) melalui aliran darah, atau PTTH, (prothoracicoptropic hormone) dan ecdysone. Hormon otak diproduksi oleh sel-sel neurosecretory pada otak dan masuk ke dalam pembuluh darah melalui struktur asesori otak. Kemudian bersirkulasi ke tempat aktivasi pada protoraks serangga. Kelenjer kecil di protoraks (prothoracic gland) distimulasi untuk mensekresikan ecdysone (hormon molting, juga dinamakan hormon protoracid gland) yang memicu pertumbuhan dan aktivasi molting sel-sel (Hadi dkk. 2009). Sudarmadji (1994) menambahkan bahwa apabila serangga telah mengalami keracunan oleh senyawa kimia azadirachtin maka proses fisiologisnya akan terganggu yang ditandai dengan perubahan perilaku (terjadi penolakan makan, mengganggu pertumbuhan atau reproduksi secara struktural, larva menjadi tidak aktif (stress) dan akhirnya akan mengalami kematian.

Penggunaan daun mimba dapat menimbulkan dampak fisiologis yaitu langsung dan tidak langsung. Dampak secara tidak langsung berpengaruh terhadap sistem endokrin. Sistem neurosecretory otak dipengaruhi oleh azadirachtin yang menyebabkan penyumbatan pengeluaran hormon morphogenetic peptida mis PTTH (hormon prothoracicotropic) dan allatostatins. Hormon ini mengontrol fungsi kelenjar 
prothoracic dan corpora allata. Hormon Moulting (â-hydroxyecdysone) dari kelenjar prothoracic pada gilirannya mengontrol formasi baru kutikula dan ecdyses (tindakan extrication dari kutikula lama) sedangkan hormon juvenil (JH) dari corpora allata mengontrol pembentukan tahap remaja serangga. Dalam keadaan dewasa kedua hormon ini dapat terlibat dalam pengendalian deposisi kuning pada telur. Gangguan yang terjadi biasanya pada disfungsi mulut dan berdampak pada kemandulan. Secara langsung, azadirachtin berpengaruh pada sel-sel dan jaringan. Azadirachtin diserap ke dalam sel dan menyebabkan penghambatan kedua sel pision dan sintesis protein.

Daun mimba juga mengandung senyawa aktif lain yang dapat mempengaruhi kerja sebagai larvasida ataupun insektisida yaitu senyawa salannin dan nimbenen. Senyawa salannin mempunyai daya kerja sebagai penghambat makan serangga (antifeedant). Senyawa nimbinen mempunyai daya kerja sebagai antivirus dan meliantriol mempunyai daya kerja penolak serangga (repellent). Daya antifeedant dapat menyebabkan serangga tidak mau bertelur atau menolak memakan media pada masa infestasi. Salanin berperan sebagai penurun nafsu makan (antifeedant) yang mengakibatkan daya rusak serangga sangat menurun, walupun serangganya sendiri belum mati. Meliantriol dan salanin dapat mempengaruhi serangga menolak untuk makan sehingga akhirnya serangga mati kelaparan, namun tidak mempengaruhi proses pergantian kulit serangga. Ekstrak daun mimba dapat dengan cepat terserap melalui permukaan kulit, melumpuhkan urat syaraf dan menyebabkan kematian dengan segera. Selain itu racun yang terkandung pada daun mimba akan berpengaruh dalam proses pencernaan makanan, menghambat kontraksi usus, sehingga proses pencernaan makanan tidak dapat berlangsung.

Berdasarkan hal tersebut, ektraksi daun mimba mempengaruhi serangga melalui berbagai macam cara, antara lain menghambat stadium larva, mengganggu kopulasi dan komunikasi seksual serangga, mencegah betina untuk meletakkan telur, menghambat reproduksi atau menyebabkan serangga mandul, meracunilarva dan dewasa, dan mengurangi napsu makan atau memblokir kemampuan makan. Oleh karena itu, dalam menggunakan pestisida nabati dari mimba, seringkali hamanya tidak mati seketika setelah diaplikasi (knock down), namun memerlukan beberapa hari untuk mati, biasanya 4-5 hari. Namun demikian, hama yg telah terpapar tersebut daya rusaknya sudah sangat menurun, karena dalam keadaan sakit. Daya repellent berfungsi untuk menghambat peletakan telur oleh serangga betina, karena serangga hanya mau bertelur pada tempat yang cocok bagi keturunannya. Penghambatan juga terjadi oleh adanya pengaruh bau atau aroma ekstrak yang berupa komponen aktif yang ada pada ekstrak daun mimba (Kardinan, 2000). Aromanya ini akan menghindarkan daging dari kehadiran lalat sehingga ini dapat menghindarkan dari pembusukan.

Kandungan flavonoid, alkaloid dan tannin dalam daun dapat menghambat pertumbuhan bakteri dan motilitas bakteri, merusak membran sel bakteri sehingga sel bakteri akan lisis (koagulator protein) terutama dalam proses remodeling serta menghambat pertumbuhan fibroblast sehingga perawatan luka akan lebih mudah. Selain itu, tannin berfungsi sebagai adstringen yang dapat menyebabkan penciutan pori-pori kulit, memperkeras kulit, menghentikan eksudat dan pendarahan yang ringan, sehingga mampu menutupi luka dan mencegah pendarahan yang biasanya timbul. Selain itu, saponin merupakan antimikroba dan memiliki kemampuan sebagai pembersih dan antiseptik sehingga luka tidak mengalami infeksi berat dan saponin memiliki tingkat toksisitas yang tinggi terhadap fungi dan meningkatkan kandungan kolagen serta mempercepat proses epitalisasi sehingga proses penyembuhan luka akan lebih cepat.

Kompleksitas struktur molekul azadirachtin menghalangi sintesis untuk penggunaan pestisida. Daun nimba mengandung azadirachtin bersama-sama dengan beberapa molekul yang terkait 
secara struktural telah membentuk dasar dari penggunaan nimba mengendalikan serangga. Pendekatan masa depan juga dapat mencakup produksi azadirachtin untuk pengendalian serangga oleh di kultur jaringan in vitro dari nimba. Insektisida dari tanaman nimba efektif terutama sebagai mengatur pertumbuhan serangga dan sterilants. Ekstrak nimba telah banyak digunakan sebagai pestisida di pertanian. Di negara-negara barat utama dunia seperti Amerika Serikat dan Kanada dan di Eropa beberapa insektisida dari tanaman nimba yang dikomersialkan telah mencapai pasar sampai saat ini. Azadirachtin mudah terabsorbsi oleh tanaman, bekerja secara sistemik, sedikit racun kontak dan aman bagi serangga musuh alami.

\section{SIMPULAN}

Berdasarkan penelitian yang telah dilakukan, dapat disimpulkan bahwa perlakuan daun mimba konsentrasi $25 \%$ memberikan jumlah kematian larva yang lebih tinggi dibandingkan terhadap kontrol positif dengan perbedaan persentase sebesar $60 \%$. Sehingga dapat dikatakan bahwa daun mimba lebih efektif sebagai larvasida jika dibandingkan dengan minuman bersoda. Dengan demikian, proses perebusan daging dengan daun mimba yang akan digunakan sebagai sarana upacara dapat dilakukan untuk menghindari pembusukan yang disebarkan oleh lalat daging (Sarchopaga).

\section{SARAN}

Saran yang disampaikan dalam penelitian ini yaitu (1) bagi peneliti disarankan untuk melakukan penelitian lebih lanjut untuk mengetahui persentase kandungan zat aktif yang terkandung dalam rebusan daun mimba dalam menghambat pertumbuhan Larva lalat daging (Sarcophaga), serta melakukan penelitian terhadap rebusan daun mimba ini dapat dilanjutkan dengan mengujikannya pada jenis larva lain untuk menambah khasiat dari daun mimba., serta laporan ini dapat dijadikan sebagai referensi. Masyarakat khususnya masyarakat bali disarankan untuk memanfaatkan daun tanaman mimba (Azadirachta indica) untuk mengawetkan daging yang digunakan pada upakara di
Bali dengan cara merebus daun dengan air terlebih dahulu dan merendam daging dengan rebusan daun mimba selama 30 menit.

\section{DAFTAR PUSTAKA}

Biswas, K., Chattopadhyay, I., Banerjee, R. K., \& Bandyopadhyay, U. (2002). Biological activities and medicinal properties of neem (Azadirachta indica). Current Science, 82(11), 1336-1345.

Byrd, J. H., \& Castner, J. L. (2001). Insects of Forensic Importance in Forensic Entomology: The Utility of Arthropods in Legal Investigation. New York: CRC Press.

Chandra, B. (2005). Pengantar Kesehatan Lingkungan. Jakarta: Penerbit Buku Kedokteran (EGC).

David, B.V., Anathakrishnan, T. N. (2004). General and Applied Entomology. New Delhi: Tata Mc Graw - Hill Companies.

Fathoni, M., Yanuwiadi, B., \& Leksono, A. S. (2013). The effectiveness of combination Mahogany (Swietenia mahogany) seed and Sour Sup (Annona muricata) leaf pesticide to the time of stop feeding and LC50 mortality on armyworm (Spodoptera litura F.). Journal of Biodiversity and Environmental Sciences (JBES), 3(11), 71-77.

Graczyk, T. K., Knight, R., \& Tamang, L. (2005). Mechanical Transmission Of Human Protozoan Parasites By Insects. Clinical Microbiology Reviews, 18(1), 128-132.

Hariana, A. (2013). Tumbuhan Obat dan Khasiatnya. Jakarta: Penebar Swadaya.

Kardinan, A. (2000). Pestisida nabati, Ramuan dan Aplikasi. Jakarta: Penebar Swadaya.

Mordue (Luntz), A. J., Simmonds, M. S. J., Ley, S. V., Blaney, W.M. , Mordue, W., Nasiruddin, M., \& Nisbet, A. J. (1998). Actions of azadirachtin, a plant allelochemical, against insects. Pesticide Science, 54(3), 277-284.

Pritima, R.A., Pandian, R. S. (2008). Antibacterial Potency of Crude Extract of Azadirachta indica A. Juss (Leaf) 
Against Mirobes Causing

Reproductive Tract Infections Among

Women. Current Biotika, 2, 2-6.

Samsudin. (2011). Biosintesa dan cara kerja azadirachtin sebagai bahan aktif insektisida nabati. Semnas Pesnab IV, 61-70.

Santi, D. N. (2001). Manajemen Pengendalian Lalat. Fakultas Kedokteran Universitas Sumatera Utara.

Sudarsana, I. P. . (2010). Himpunan Tetandingan Upakara Yadnya. Denpasar: Percetakan Bali.

Susanti, N. D., Sukesi, T. W., \& Soeyoko. (2012). Efektivitas Ekstrak Etanol Daun Mimba(Azadirachta Indica A. Juss) Sebagai Larvasida Terhadap Larva Aedes Aegypti, 46-53. 